\title{
Enterprise resource planning: An assessment for readiness to change
}

\author{
Ali Ashraf Nazari ${ }^{\mathrm{a}}$, Rahmatollah Mohammadipour ${ }^{\mathrm{b} *}$ and Farshid Namamian ${ }^{\mathrm{a}}$
}

${ }^{a}$ Department of Management, Kermanshah Branch, Islamic Azad University, Kermanshah, Iran

${ }^{b}$ Department of Accounting, Science and Research Branch Branch, Islamic Azad University, Ilam, Iran

\section{H R O N I C L E}

Article history:

Received Feb 28, 2013

Received in revised format

19 September 2013

Accepted 23 October 2013

Available online

November 202013

Keywords:

Enterprise resource planning

Readiness

Assessment

\section{A B S T R A C T}

This paper presents an empirical investigation for the implementation of enterprise resource planning among 58 production units in province of Ilam, Iran. The proposed study of this paper considers the readiness in terms of six factors including human resources, financial resources, infrastructures, quality control, and information systems and communication technology. Using structural equation modeling, the study examines six hypotheses and the implementation is accomplished on LISREL software package. Cronbach alpha has been calculated as 0.91 , which is well above the minimum desirable level. The results of the survey have indicated that all six mentioned factors influence positively on ERP implementation and for a successful implementation of ERP, it is suggested to consider these factors, seriously.

(C) 2014 Growing Science Ltd. All rights reserved.

\section{Introduction}

The success of enterprise resource planning (ERP) implementation is one of the serious concerns among business owners (Somers \& Nelson, 2001). In fact, there is a growing competition among most organizations and ERP planning has become one of the primary tools to reach competitiveness in business. ERP is an infrastructure to create and to maintain business to improve front-office and back-office efficiency and effectiveness. Candra (2012) presented an insights in determines the key antecedents to successful ERP implementation based on knowledge capability perspectives and understanding the key success factor in ERP implementation. They reported that knowledge capability could influence the success of ERP implementation. Hong and Kim (2002) performed an empirical investigation to find the critical success factors for ERP implementation. Xu et al. (2006) presented a study on integrating knowledge management (KM) and ERP in enterprise information systems. They discussed how to deploy KM and ERP simultaneously in the framework of enterprise information systems, by giving an insight of the interaction of KM and ERP systems in systems

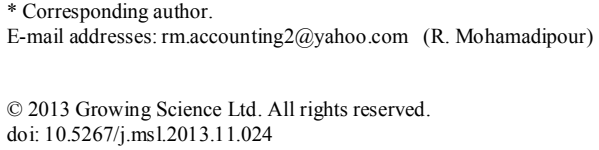


perspectives. Xue et al. (2005) performed an empirical investigation on ERP implementation failures in China and reported eight factors, which have contributed to ERP failure.

Motwani et al. (2002) examined different factors, which could facilitate or inhibit the success of ERP projects and necessary actions to control ERP projects, which are in trouble. The study applied a case study methodology grounded in business process change theory to compare a successful ERP implementation with failed one. They reported that a cautious, evolutionary, bureaucratic implementation process backed with careful change management, network relationships, and cultural readiness could lead to a successful ERP project implementation as opposed to a revolutionary project scope mandated autocratically by top management without organizational readiness and proper change management.

Vandaie (2008) studied the role of organizational knowledge management in successful ERP implementation projects. The paper concluded that in order to implement ERP systems to improve the sharing of enterprise-wide information and knowledge, organizations must have the ability of effective knowledge sharing to start with. $\mathrm{Xu}$ and $\mathrm{Ma}$ (2008) discussed determinants of ERP implementation knowledge transfer. Scheer and Habermann (2000) discussed how to bring an ERP project into a successful project.

Kim et al. (2005) performed an investigation on impediments to successful ERP implementation process and reported that most of critical impediments were from functional coordination problems associated with inadequate support from functional units and coordination among functional units, the project management associated with business process change, and change management associated with resistance of users. They also categorized impediments based on project phases, and differences.

According to Azad et al. (2013), ERP systems have been used in many organizations and many business units have been trying to emerge into an integrated system. There are different advantages on having an efficient ERP but most corporations fail to reach a full operational ERP for various reasons. They presented an empirical investigation to detect important factors influencing ERP implementation in one of the biggest Iranian automakers named Iran Khodro. They designed a questionnaire in Likert scale consists of 46 questions, distributed it among some managers in this firm. Cronbach alpha was calculated as 0.802, Kaiser-Meyer-Olkin Measure of Sampling Adequacy and Approx. Chi-Square were 0.788 and 1677.307, respectively. They derived eight factors including intelligence information, customer comfort, structure oriented, resource management, process oriented, customer oriented, flexible structure and knowledge management as important factors for ERP implementation.

Rahmani and Taghva (2012) presented a domestic model for successful implementation of ERP systems in Iranian manufacturing enterprises. It is clear that accepting a technology depends entirely on the underlying circumstances of the environment. They approached this issue from two various angles of social and technological architecture. The research tried to explore proper enterprise architecture for ERP system acceptance. Social Architecture (SA) in this survey, was defined as the set of circumstances, which makes people behave in a specific way. Therefore, behavior of employees can be a function of SA. They evaluated various variables of social architecture and examined their relevance to system acceptance and success in association with enterprises beside technological architecture variables.

The results have indicated that a special form of social and technological architecture can lead to success for ERP system in the enterprises of the research domain. This gave us a model of architecture. 


\section{The proposed study}

This paper presents an empirical investigation for the implementation of enterprise resource planning among 58 production units in province of Ilam, Iran. The proposed study of this paper considers the readiness in terms of six factors including human resources, financial resources, infrastructures, quality control, and information and communication technology. Fig. 1 demonstrates the proposed study of this paper,

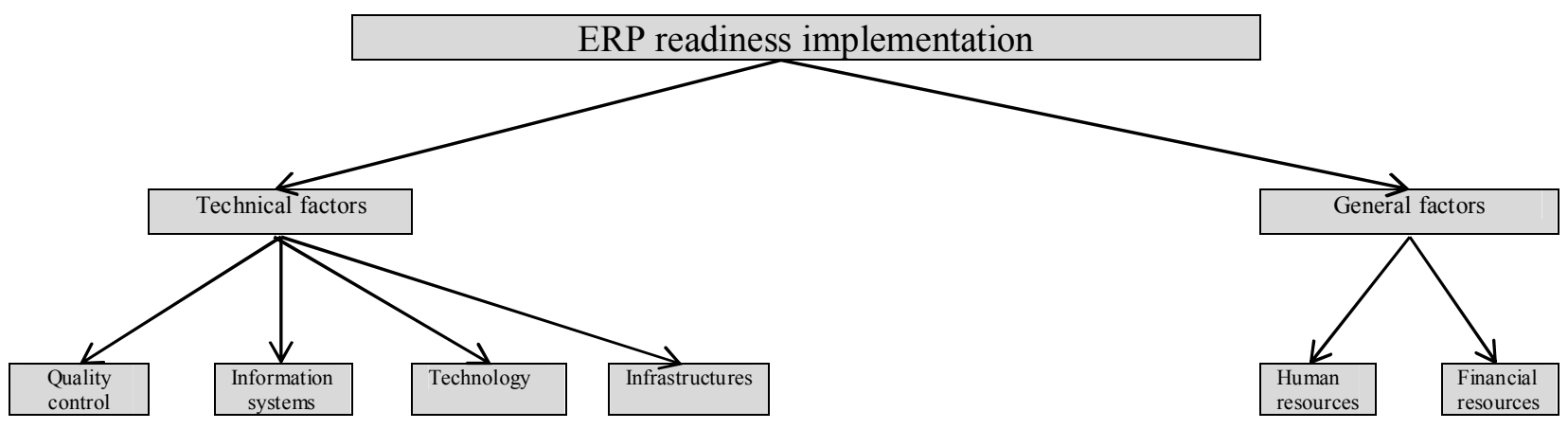

Fig. 1. The proposed study

Based on the information of Fig. 1, we consider the following hypotheses,

1. There is a meaningful relationship between the ERP implementation and human resource management.

2. There is a meaningful relationship between the ERP implementation and financial resources.

3. There is a meaningful relationship between the ERP implementation and infrastructure.

4. There is a meaningful relationship between the ERP implementation and quality control.

5. There is a meaningful relationship between the ERP implementation and information system.

6. There is a meaningful relationship between the ERP implementation and technology.

The first step to examine different hypotheses of the survey is to make sure the data are normally distributed using Kolmogorov-Smirnov $\mathrm{Z}$ and the results of our survey are presented in Table 1 as follows,

\section{Table 1}

The summary of Kolmogorov-Smirnov statistics

\begin{tabular}{ccccccc}
\hline Readiness & $\begin{array}{c}\text { Information } \\
\text { technology }\end{array}$ & $\begin{array}{c}\text { Information } \\
\text { system }\end{array}$ & $\begin{array}{c}\text { Quality } \\
\text { control }\end{array}$ & Infrastructure & $\begin{array}{c}\text { Financial } \\
\text { resources }\end{array}$ & $\begin{array}{c}\text { Human } \\
\text { resources }\end{array}$ \\
\hline 0.759 & 0.120 & 0.63 & 0.321 & 0.259 & 0.325 & 0.229 \\
\hline
\end{tabular}

The results of Table 1 indicate that all components of the survey are normally distributed when the level of significance is five percent.

\section{The results}

In this section, we present details of our findings on testing the main and sub-hypotheses of the survey. 


\subsection{The main hypothesis}

Fig. 2 demonstrates the results of our investigation on testing the main hypothesis of the survey.

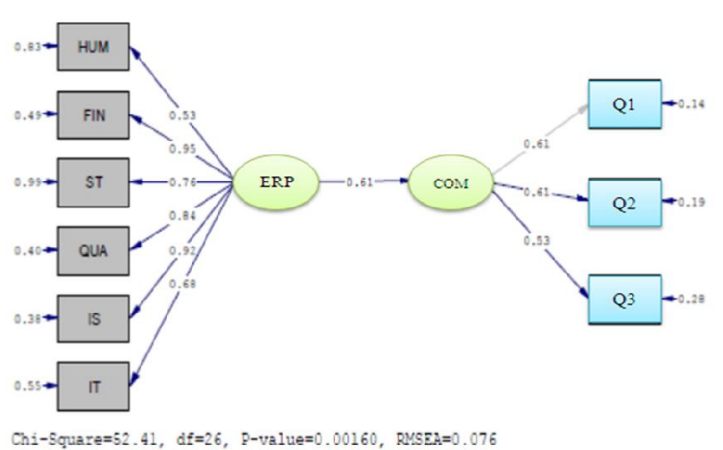

The results of standard values

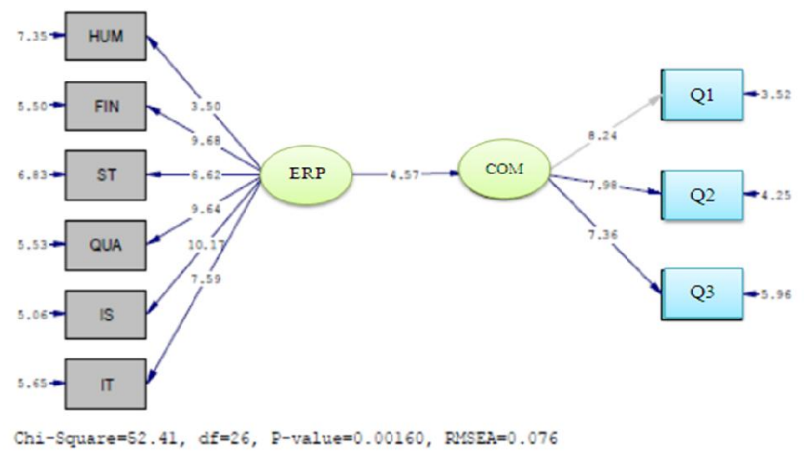

The results of t-student values

Fig. 2. The results of the implementation of structural equation modeling for the main hypothesis

As we can observe from the results of t-student values, all components are statistically significance since t-values are well above critical values, RMSEA is equal to $0.076<0.09$ and Chi-Square/df is greater than 2 with P-value $=0.00160<0.05$. Therefore, the main hypothesis of the survey is confirmed and we can conclude that firm readiness influences by six factors of human resources (HUM), financial (FIN), Infrastructures (ST), Quality (QUA), Information system (IS) and Information technology (IT).

\subsection{The results of testing sub-hypothesis}

We have also examined different sub-hypotheses of the survey and Fig. 3 demonstrates the results of our survey.

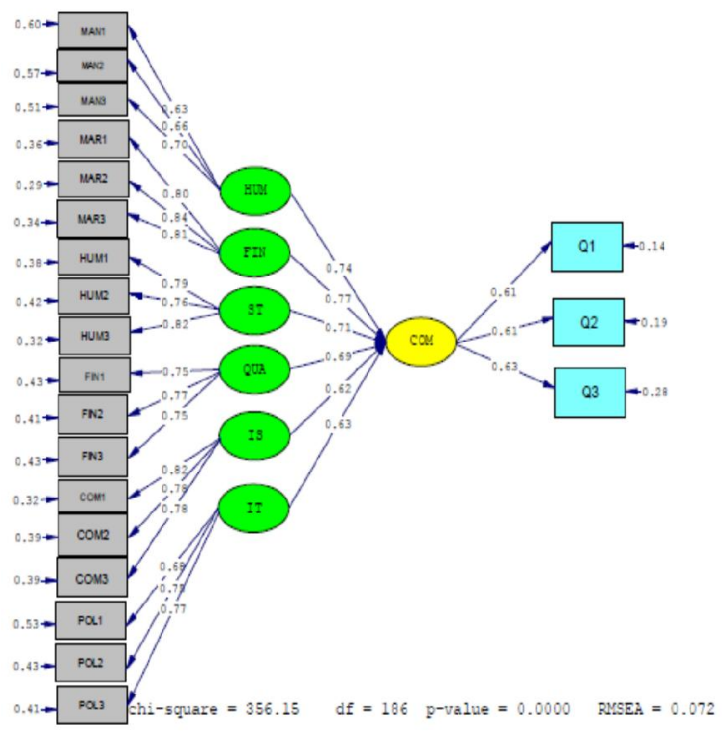

The results of standard value

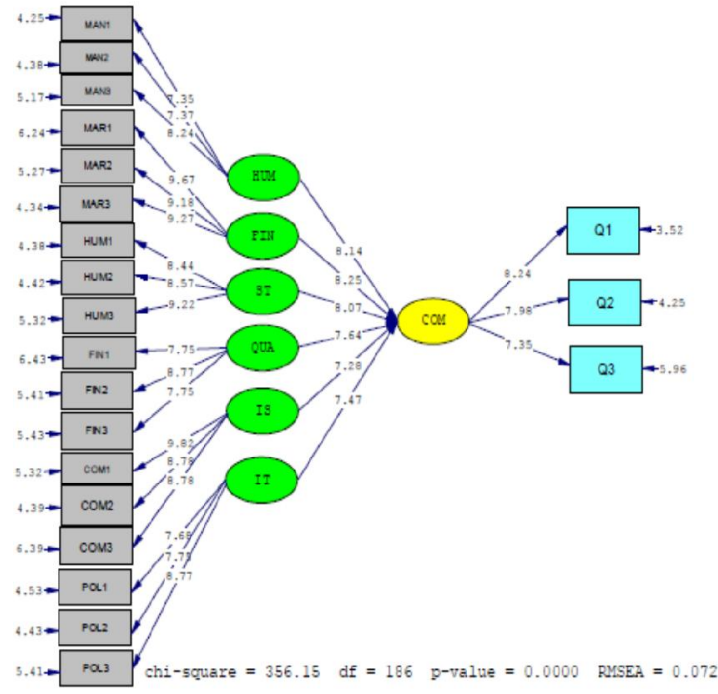

The results of t-student value

Fig. 2. The summary of testing sub-hypotheses

As we can observe from the results of t-student values, all components are statistically significance since t-values are well above critical values, RMSEA is equal to $0.072<0.09$ and Chi-Square/df is 
greater than 2 with $\mathrm{P}$-value $=0.0000<0.05$. Therefore, all sub-hypotheses of the survey are confirmed. Table 2 demonstrates the summary of our findings.

Table 2

The summary of testing sub-hypotheses of the survey

\begin{tabular}{lcccccc}
\hline & Human resources & Financial & Infrastructures & Quality control & Information system & Information technology \\
\hline$\beta$ & 0.74 & 0.77 & 0.71 & 0.69 & 0.62 & 0.63 \\
t-value & 8.14 & 8.25 & 8.07 & 7.64 & 7.28 & 7.47 \\
Results & Confirmed & Confirmed & Confirmed & Confirmed & Confirmed & Confirmed \\
\hline
\end{tabular}

According to the information of Table 2, firm readiness is mostly influenced by financial figures followed by human resources and infrastructures. Other items including quality control, information system and information technology also influence firm readiness, positively.

\section{Conclusion}

In this paper, we have presented an empirical investigation to study the impact of six factors on firm readiness to apply enterprise resources planning. The proposed study of this paper has implemented structural equation modelling and the results have confirmed that a firm with strong financial background had better chance of adopting ERP systems. In addition, human resources have been considered as key factors for successful implementation of ERP system. There is no doubt that most companies around the world depend entirely on their intellectual assets for their success. In fact, human resources are the end users of ERP systems and their cooperation can significantly contribute on the success of ERP implementation. In fact, during the past several years, over $50 \%$ of the ERP systems fail in United States and one of the main reasons to blame was the lack of good cooperation on behalf of human resources. Finally, when there are some good infrastructures within an organization, one could expect for a better chance of success within organization. In other words, an organization with insufficient infrastructures cannot reach ERP objectives.

\section{Acknowledgement}

The authors would like to thank the anonymous referees for constructive comments on earlier version of this paper.

\section{References}

Azad, N., Shadmanfard, A., \& Zarifi, S.F. (2013). An exploration study to find important factors influencing on enterprise resource planning. Management Science Letters, 3(9), 2405-2410.

Candra, S. (2012). ERP Implementation Success and Knowledge Capability. Procedia-Social and Behavioral Sciences, 65, 141-149.

Hong, K. K., \& Kim, Y. G. (2002). The critical success factors for ERP implementation: an organizational fit perspective. Information \& Management,40(1), 25-40.

Kim, Y., Lee, Z., \& Gosain, S. (2005). Impediments to successful ERP implementation process. Business Process Management Journal, 11(2), 158-170.

Motwani, J., Mirchandani, D., Madan, M., \& Gunasekaran, A. (2002). Successful implementation of ERP projects: evidence from two case studies. International Journal of Production Economics, 75(1), 83-96.

Rahmani, M., \& Taghva, M. R. (2012). A domestic model for successful implementation of enterprise resource planning (ERP) systems in Iranian manufacturing enterprises. Management Science Letters, 2(1), 67-78.

Scheer, A. W., \& Habermann, F. (2000). Enterprise resource planning: making ERP a success. Communications of the ACM, 43(4), 57-61. 
Somers, T. M., \& Nelson, K. (2001, January). The impact of critical success factors across the stages of enterprise resource planning implementations. In System Sciences, 2001. Proceedings of the 34th Annual Hawaii International Conference on (pp. 10-pp). IEEE.

Vandaie, R. (2008). The role of organizational knowledge management in successful ERP implementation projects. Knowledge-Based Systems, 21(8), 920-926.

$\mathrm{Xu}$, L., Wang, C., Luo, X., \& Shi, Z. (2006). Integrating knowledge management and ERP in enterprise information systems. Systems Research and Behavioral Science, 23(2), 147-156.

$\mathrm{Xu}$, Q., \& Ma, Q. (2008). Determinants of ERP implementation knowledge transfer. Information \& Management, 45(8), 528-539.

Xue, Y., Liang, H., Boulton, W. R., \& Snyder, C. A. (2005). ERP implementation failures in China: case studies with implications for ERP vendors. International journal of production economics, 97(3), 279-295. 